\title{
Palynology and microfacies of Lower Devonian mixed carbonate-siliciclastic deposits in Podolia, Ukraine
}

\author{
Paweł Filipiak, Michał Zatoń, Hubert Szaniawski, Ryszard Wrona, and Grzegorz Racki \\ Acta Palaeontologica Polonica 57 (4), 2012: 863-877 doi: http://dx.doi.org/10.4202/app.2011.0184
}

Investigation of mixed carbonate-siliciclastic Lower Devonian deposits have been carried out in the Ivanye Zolote and Ustechko sections in Podolia, Ukraine. Based on palynomorph evidence, the age of the samples studied is late Lochkovian, not older than the NM Oppel Miospore Zone, specifically the Si Lineage Zone. The presence of acritarchs and chitinozoans points to dominantly marine depositional conditions. However, a regressive environmental change toward more brackish conditions is indicated by a decrease in the taxonomic diversity of acritarchs in the topmost samples, the simultaneous disappearance of chitinozoans, and an increase in leiosphaerid frequency. Furthermore, evolution of limestone microfacies demonstrates a progressive transition from a shrinking marine basin toward a brackish, storm-affected muddy lagoon, manifested by recurrent profusion of impoverished, mostly opportunistic and euryhaline shelly benthos (nuculanid bivalves, leperditicopids and other ostracods, terebratulid brachiopods), chaetetid demosponges and diverse ichthyofauna. The association of plant (mainly nematophytes and some tracheids) and animal (eurypterid, ?scorpion, and possibly other arthropod) remains points to the presence of nearby Early Devonian wetland vegetation, providing food and shelter for various semi-aquatic and other terrestrial arthropods.

Key words: Eurypterids, palynostratigraphy, palynofacies, carbonate microfacies, cuticles, Lower Devonian, Podolia.

Paweł Filipiak [ilipiak@us.edu.pl], Michał Zatoń [mzaton@wnoz.us.edu.pl], and Grzegorz Racki [grzegorz.racki@us.edu.pl], Faculty of Earth Sciences, University of Silesia, Będzińska 60, PL-41-200 Sosnowiec, Poland; Hubert Szaniawski [szaniaw@twarda.pan.pl] and Ryszard Wrona [wrona@twarda.pan.pl], Institute of Paleobiology, Polish Academy of Sciences, Twarda 51/55, PL-00-818 Warszawa, Poland.

This is an open-access article distributed under the terms of the Creative Commons Attribution License (for details please see creativecommons.org), which permits unrestricted use, 
distribution, and reproduction in any medium, provided the original author and source are credited.

FaF Full text $(1,361.2 \mathrm{kB})$ 